\title{
LXXXVII. On the former extent of the Persian Gulf, and on the non-identity of Babylon and Babel; in reply to Mr. Carter
}

\section{C.T. Beke Esq. F.S.A.}

To cite this article: C.T. Beke Esq. F.S.A. (1836) LXXXVII. On the former extent of the Persian Gulf, and on the non-identity of Babylon and Babel; in reply to Mr. Carter, Philosophical Magazine Series 3, 8:49, 506-515, DOI: 10.1080/14786443608648929

To link to this article: http://dx.doi.org/10.1080/14786443608648929

曲 Published online: 01 Jun 2009.

Submit your article to this journal $\pi$

Џll Article views: 2

Q View related articles $₫$ 
LXXXVII. On the former Extent of the Persian Gulf, and on the Non-identity of Babylon and Babel; in Reply to Mr. Carter. By C. T. Beke, Esq., F.S.A.

To the Editors of the Philosophical Magazine and Journal. Gentlemen,

THE opinion which was, in the first instance, advanced by me in the Number of your Journal for February 1824*, was to the effect that the low lands of the Euphrates and Tigris have been formed by the gradual deposits of those rivers, and that this operation has been so extensive, that, at the time of the erection of the Babel of Genesis, it must have been physically impossible for that city to be built near the spot where the Babylon of Nebuchadnezzar afterwards stood. This opinion may be considered as embracing two distinct and separate propositions:- the first is that, within the period of history, an advance of the land upon the sea has taken place of sufficient importance to affect materially the geography of the localities in question; the second is that, within the same period, that advance has been so great as (independently of all other arguments,) to warrant my conclusion with respect to the non-identity of Babylon and Babel. If the former of these propositions be untrue, a fortior $i$ must the latter be so; but, on the other hand, even if the former be established, it does not follow that the latter is likewise correct.

From Mr. Carter's former arguments I certainly was led to consider, that he not merely disputed the correctness of the first proposition to its entire extent, but that he went yet further, and contended that the changes (if any) which have taken place, are altogether insignificant. In his present remarks he says, however $\dagger$, "I much object to such expressions in the reply as, "Mr. Carter has, in fact, asserted the opinion that, since the time of Nearchus, the encroachments on the gulf must be very unimportant,' omitting the words 'to the point in question, any later encroachments,' \&c., as conveying the idea of a mere assertion without proof, and a much broader one than my remarks warrant." I am most anxious that no difference should exist between us on the score of mere misconception of each other's meaning, and I therefore give at length, in the note at foot, an extract of the whole passage from which I made my citation $\downarrow$; and $I$ put it to the candour

* Lond. and Edinb. Phil. Mag., vol. iv. p. 108-111.

+ Supra, vol. vii. p. 195.

\pm "Following the course of Nearchus, as given in his own clear account of the voyage preserved by Arrian, from his arrival at the Arosis, the river 
of my opponent himself, whether I was not fairly authorized in the conclusion which I came to with respect to bis meaning: indeed I would ask whether, when in his present reply he says, with respect to "the navigation of Alexander and his fleet in the delta streams," that "the ancient canal, the entire circuit, all the points of the navigation then presented by the spot, are still offered for our observation," it must not be understood as his unqualified opinion that "since the time of Nearchus the encroachments on the gulf have been very unimportant." If I am so unfortunate as still to misunderstand his meaning, I beg to assure him that I do so most unintentionally.

As regards the observation that my words "convey the idea of a mere assertion without proof," Mr. Carter must allow me to say, that a construction appears to be put upon them which ought not by any means to be adoptedo in a discussion like the present. Every proposition advanced, or assertion made, on either side, must be presumed to be made upon what are regarded as "proofs;" and it is simply from the considered insufficiency of those alleged proofs that the correctness of any such proposition or assertion is questioned on the other side. For my part, I feel that I might have reason to object, not merely to some expressions, but also to the tone generally in which Mr. Carter's last reply is written; but I refrain from doing so, and I sincerely trust that neither of us will have occasion again to refer to any such unpleasant topic.

In order to prevent any future misconception, it is to be understood that the first and principal point in dispute between us is, whether a change of such importance has taken place as materially to affect the geography of the localities in

at the N.E. next before coming to the streams of the Delta, in his progress to Kataderbis and the island of Margastana, in his passage through the channel over the shoals to his arrival at Diridotis (by the Khore Abdallah), on the S.W. side of the Delta, and comparing it with the present state of the country, we learn with surprise the small degree of change which the general characters of the coast have undergone during the lapse of so many ages. Dr. Vincent, in his able work on the Commerce and Navigation of the Ancients in the Indian Ocean, adverting to this remarkable fact, $n b-$ serves, that Capt. Howe's chart 'explains the journal of Nearchus as perfectly as if it had been composed by a person on board of his fleet,' (vol. i. p. 423.) and (p. 466.) "the pilot on board Nearchus's ship steered exactly the same course' (along the coast of the Delta) 'as MacCluer's Karack pilot 2000 years afterwards.' The junction of the river called by Arrian the Eulæus (coming from the N. or N.E.) with the Tigris by the still existing ancient Hoffar canal, across which Alexander sent a part of his fleet while he sailed down the Eulæus to the mouths of the Tigris, and so round to meet it (Arrian, Exp. Alex. vii. 7.) further shows that to the point in question any later encroachments on the gulf must be very unimportant." Lond. and Edinb. Phil, Mag, vol. v. p. 247-8. The Italic's are Mr. Carter's. 


\section{Mr. Beke on the former Extent of the Persian Gulf,}

question; that is to say, a change so great as to render the descriptions of ancient writers inapplicable to the actual coastline and state of the neighbourhood generally.

Seeing that my hypothesis precludes the possibility of Nearchus's voyage being made applicable to the present coast of Susiana and the countries at the head of the Persian Gulf, it is scarcely necessary for me expressly to dispute in detail the correctness of the identifications, considered to have been established by Dr. Vincent, of the river Arosis, of Kataderbis, the island of Margastana, Diridotis, \&c. \&c.* That the river Karoon is not the Eulæus, nor Shuster the representative of Susa, has already been asserted by many geographers of eminence, whose voices are united in favour of Shus and the river Haweeza or Kerrah. Without intending to range myself with these geographers, I believe I am correct in saying that, as between them and Dr. Vincent, the greater show of reason is

- Although I am quite willing to concede that "a few miles of addition to the Delta is not the question" between us, yet, as regards the learned Dean's identifications, I must remark, that a few miles-nay, a very few miles indeed-of addition would (I much suspect.) render it impossible that "Capt. Howe's chart should explain the journal of Nearchus as perfectly as if it had been composed by a person on board of his fleet." To establish the correctness of this position, it appears to be necessary, not merely that the coast should have remained unvaried since the time of the Greek navigator, but that Capt. Howe's chart should accurately represent that coast: it ought, consequently, to correspond in all points with the trigonometrical survey recently made by Lieuts. Brucks and Haines, of the East India Company's Marine Service.

By the kindness of Capt. Horsburgh I have been furnished with copies of the Company's chart, as also of that of Lieut. MacCluer (by Dalrymple, 1786 and 1788): Capt. Howe's he was not in possession of. Owing to the longitude not being marked in MacCluer's, I am prevented from making an exact comparison of these two charts; still differences of sufficient moment are to be detected between them. For instance, the island of Karack is represented by MacCluer as being 8, and Korgo more than 4 geographical miles long, whereas they are actually just half those lengths respectively : Buna (Derabuna), by the Core Moosah, is made as much as 9 miles long, from north to south, and 3 miles broad, whilst it is only 3 miles long, and less than 1 mile broad, its length being from east to west: Derah, adjoining this last island, is made 7 miles long and 3 miles broad, but it is in fact only a mile and a half each way : the Core Abdallah, represented in the copy of 1786 as being 10 miles broad, with 8 miles of coast between it and the mouth of the Bussorah river, and in that of 1788 as only 6 miles broad, with about 10 miles of coast, is actually 12 miles broad, and the two mouths meet at a point, without any coast intervening. These variations (which are only a portion of what might be pointed out,) may be said to be but trifles with respect to "the general characters of the coast;" still they are more than sufficient to show that MacCluer's chart would have been rather a dangerous guide for Nearchus to have placed implicit confidence in. Capt. Howe's chart, which was adopted by Dr. Vincent, is (I believe) not even so correct as that of MacCluer; but I have not at present the means of referring to the Dean's work, so as to ascertain this positively. 
on their side. Under their hypothesis, however, Charax, which was situate at the 'confluence of the Tigris and Eulæus, will have to be placed not 37 but about 100 miles up the river; so that "the plain fact" by which "even the increase of 35 miles" in the distance of that city from the sea is "annihilated" in so summary a manner, is not quite so manifest. The position of Charax remains, I conceive, yet to be determined; but, let it have been where it may, I confess I do not exactly understand how my "extravagant hypothesis" is to be "at once disposed of," for the reason that, "if the distance of Charax, the port, had increased but 70 miles" (or it may be only 35 miles,) between the times of Alexander and Pliny (400 years), "the whole distance to Babylon could have increased but 70" (or 35) miles in the 2160 years which have elapsed since the voyage of Nearchus down to the present time. Leaving the "extravagant hypothesis" quite out of the question, it appears to me that, assuming the same rate of increase throughout the whole period, the gain would be about 380 (or 190) miles.

The "diversitas auctorum" of which Pliny complains, is a point upon which Mr. Carter makes a great stand; and hence he comes to the strange conclusion, that the distance between Babylon and Charax was "utterly uncertain." Now it may be perfectly comprehensible that the naturalist should have been in difficulty upon the subject, and unable to arrive at any satisfactory result, on account of the apparent discrepancies among the various authorities which were before him; yet it will not, I presume, be thence argued, that either Babylon or Charax was so situate as not to have been perfectly easy of access, so that the distance between them might always have been ascertainable, in the same way as it would be in the present day (and perhaps with less difficulty, were both cities in existence. There is not the slightest reason, therefore, for imagining that "the distance was utterly uncertain." The various authors must be presumed to have made their several statements upon good grounds, and with a competent knowledge of the actual distance; and whatever discrepancies may be found among them, beyond those which will always exist where distances are only estimated and not actually measured, are mainly, if not entirely, to be attributed to differences in the standards of measurement employed by them respectively. And this, in fact, is what Pliny himself says: "Inconstantiam mensure" (the measure itself and not the distance measured,) "diversitas auctorum facit: cum Persce quoque schoenos et parasangas, alii alia mensura determinent*." This difficulty be-

${ }^{*}$ Hist. Nat., lib. vi. cap. 27. 


\section{$510 \mathrm{Mr}$. Beke on the former Extent of the Persian Gulf,}

comes no slight one when, as was frequently the case, those standards of measurement, although of widely different lengths, had the same name ${ }^{*}$; added to which, we must bear in mind that the various distances recorded were, at various times, applicable to different states of the country, in those portions of it which were liable to change. The possible existence of errors of copyists is, of course, not to be lost sight of; but I question much whether we may be authorized to entertain "serious doubts of the authenticity" of passages which do not exactly coincide with our preconceived notions.

In his former paper $\uparrow \mathrm{Mr}$. Carter cites various authorities in illustration of the passage from Pliny, in part originally quoted by me ; which passage he understands (though I cannot conceive how,) to mean that "long before Pliny's time the two rivers had united above the embouchure somewhere, not by encroachments on the gulf and formation of delta, but simply by the labour of hands;" and in his present reply that gentleman repeats that those various authorities "all harmonize with the unbroken sense of this passage:" meaning, of course, as it is interpreted by him. I confess that in my last answer I dismissed these authorities rather summarily, and I did so on account of my not being able to discover their application, and on account also of the "discrepancies" existing among them, which my opponent himself admitted $\$$. And on this point an explanation is due from me to Mr. Carter. In your Number for June last (1835), I stated that "these authorities, according to his (Mr.C.'s) admission, contain 'some discrepancies,' and are not always 'very explicable,'" in which I was thus far wrong: the being not "very explicable" was (as he now observes,) "distinctly applied by him to Pliny's general account of the two rivers only," the "discrepancies" having

* We have a precisely analogous case in the various miles of the present day, and we may easily conceive the case of a geographer in future ages being strangely perplexed on this account. Take, for instance, the distance between St. Petersburg and Riga, which by a Swede would be said to be 50 miles; by a German, 71 miles; and by an Englishman, 285 or 330 miles; whilst a Frenchman would call it 95 or 118 leagues, and a Russian 495 wersts; to which might be added, perhaps, twenty other measures of modern Europe (principally miles), all differing with one another. Here would be ample ground for complaining, as Pliny did, of the "inconstartia mensurce," but certainly none for the conclusion that "the distance was utterly uncertain."

+ Lond. and Edinb. Phil. Mag., vol. v. p. 249 .

f "Inter duorum amnium ostia 25 mill. pass. fuere, aut (ut alii tradunt) 7 mill. utroque navigabili. Sed longo tempore Euphratem præclusere Orcheni, et accolæ agros rigantes; nec nisi Pasitigri defertur in mare."-Hist. Nat., lib. vi. cap. 27.

\$ "But notwithstanding some discrepancics, the conclusion from the above authorities surely is," \&c. 
been intended by him (as will be seen from the last note,) to apply merely to the rest of the authorities cited by him. I am most happy to be able thus to correct my error.

As regards these various "harmonizing," "discrepant" authorities, I even now refrain from considering them in detail; for it would only needlessly be taking up much room, since my remarks would be little more than the continued repetition, with respect to each of them individually, of the assertion which I make respecting them collectively; namely, that I am unable to see their applicability, either to Pliny's statement as above explained by Mr. Carter, or to the present condition of the country. It will not be denied that the general conclusion from them is, that the two rivers in question " have, at a very early period, united inland somewhere ;" but I cannot conceive by what possible means the further conclusion is to be arrived at from them, that "Khorna was the grand confluence in all ages*;" for the two rivers may, by the union of their deltas, have formed a junction at some point much further inland, and yet, for ages afterwards, have still continued their (in part) separate courses to the sea.

Among the many writers thus cited by Mr. Carter, is the geographer Ptolemy, to whom, however, whilst he quotes the particular passages from the other authors which he considers applicable, he refers only in general terms. Yet Ptolemy's description of these rivers, and the countries through which they flow, is that, perhaps, which is the most important of the whole, and which, consequently, requires to be more particularly considered. 'The purport of this description appears to be as follows: That to the north of Babylon the Euphrates divided itself into two streams, whereof the one flowed southward by that city, and the other eastward past Seleucia: that between these two branches of the Euphrates there was a river called the Basilius, which, on the one hand, fell into the Tigris below Apamea, and, on the other hand, joined the main stream of the Euphrates flowing past Babylon, at some distance below that city: that the Euphrates likewise threw off an arm called the Baarsares; and that both this arm and also the main stream itself, continued their courses southward, and divided themselves into several subordinate branches, with which they formed lakes and marshes towards the head of the Persian Gulf $\uparrow$.

The Alexandrian philosopher's account must, of course, be

- How does such a conclusion tally with the notion that the Orcheni "united" the two rivers "simply by the labour of hands"? Did they make the junction at Khorna?

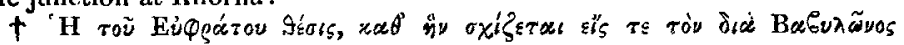




\section{$512 \mathrm{Mr}$. Beke on the former Extent of the Persian Gulf,}

taken with all the imperfections in geographical knowledge belonging to his age; but the whole context affords a manifest indication that, so late as about his time, (the beginning of the second century of our æra,) the Euphrates possessed its separate delta, of which the apex was above Babylon, and of which the western branches formed lakes and marshes below that city; whilst (although the junction is not mentioned,) the most eastern branch, as it passed by Seleucia, must have joined the Tigris. The outlet of the lakes and marshes into the sea is also not described; in fact, as Pliny tells us, it was already closed up by the Orcheni: but the authorities cited by Mr. Carter, as also Herodotus to whom I shall presently refer, plainly show that, at an earlier period, the delta streams of the Euphrates had their separate union with the Persian Gulf. In my last paper* I attempted to show how these lakes and marshes at the mouths of the Euphrates would, in the first instance, have been produced, and how, subsequently, the branches of the river which formed them would successively have been stopped and filled up by the operation of natural means, the western branches being those which were first closed. The Orcheni would have finished the work of nature by stopping up the eastern arm, which, till then, discharged itself into the sea, not more than 25 or 27 miles (as stated by Pliny,) from the western mouth of the 'Tigris; and the lakes and marshes of the Euphrates, having no longer a channel through them, would then gradually have become silted up, in the manner I have further suggested in the same paper. Much light would be thrown upon the subject if, by local examination, it were determined (which it might be without much difficulty,) how far westward the course of any branch of the Euphrates has once extended + .

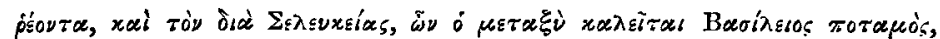

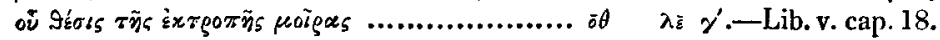

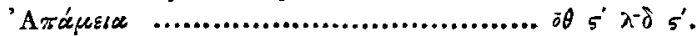

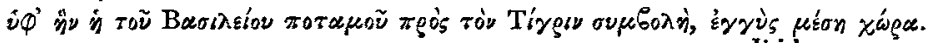
-Ibid.

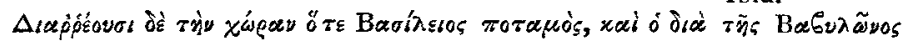

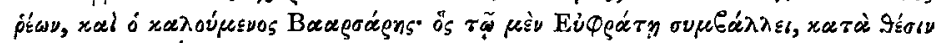

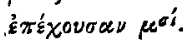
$i \theta \quad \lambda-\delta \delta^{\circ}$.

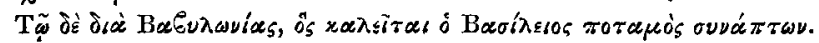
of $\lambda-\delta \gamma^{\prime}$.

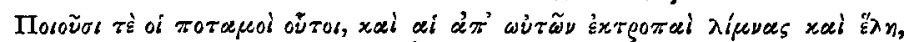

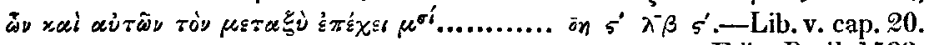

* Iond. and Edinb. Phil. Mag., vol. vii. p. 45.

Edit. Basil. 1533.

$\uparrow$ The most eastern branch of the Euphrates, which joined the Tigris above Babylon, would appear also to have become closed, unless indeed it 
At the present moment (as I have before remarked,) I do not consider that our present knowledge of the countries in question is sufficient to enable us to come to any entirely satisfactory conclusion, or to reconcile the various apparently conflicting statements of antiquity, which evidently cannot be made to apply (under favour of Mr. Carter must it be said,) to the present state of the country, and which it will require much labour and not less caution to adapt to any hypothetical condition of the country. But one point, which is not sufficiently attended to by commentators generally, cannot be too strongly borne in mind by those who may apply themselves to the task. It is, that where a fact is expressly asserted by a writer of character, who possessed the means of knowing it, its correctness must be admitted, until something positive be alleged sufficient to invalidate it. $\mathrm{Mr}$. Carter appears entirely to neglect this rule, when he cites Arrian as "saying expressly, the Euphrates has a higher channel than the 'Tigris, which receives the waters of the Euphrates by many streams," and yet, without hesitation, stigmatizes this an "error." Perfectly true it may be, as Col. Chesney reports, that, in the present day, "the Tigris gives a large contribution to the sister stream by the canal of the Hie, about 220 miles above the gulf;" but may it not be equally true, that formerly the two rivers united much higher up, at a point at which their relative levels were as Arrian so expressly states them to have been? The mere circumstance that the river Al Huali or Hermas, which at the present day runs in a direction towards the west so as to unite with the Khabour, is considered to have had in former times an eastward course and to have joined the "Tigris*, is in entire accordance with such a state of things.

Mr. Carter says, "Xenophon understood this better [than Arrian]: he mentions four canals by which the latter [the Tigris] pours its waters into the Euphrates †." Did Xenophon really say this, I should be compelled to admit his testimony, as that of a man of unquestioned honour and integrity and an eye-roitness, even in spite of the express assertion of Arrian to the contrary; but it is far from being the case, and Mr. Carter has evidently been misled from consulting merely some loose

was kept open by artificial means, in which case it would, in the result, have been regarded merely as a canal.

* See Rennell's Illustrations of the Retreat of the Ten Thousand, p. 102; see also Orig. Bibl., p. 113, where the opinion is expressed that "at the time when the extent northward of the Persian Gulf was much greater than it is at present......the river Al Huali had its separate course to the sea."

$+A n a b$., lib. i. cap. 7 .

Third Series. Vol. 8. No. 49. June $1836 . \quad 3 \mathrm{G}$ 


\section{Mr. Beke on the former Extent of the Persian Gulf.}

and inaccurate version. A reference to the original would have shown him that what the author really says respecting

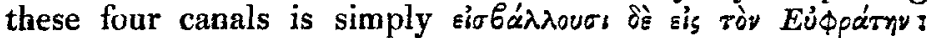
correctly rendered in the Oxford version (edit. 1676), "Iidem in Euphratem influunt," and by Spelman "they fall into the Euphrates." Smaller streams are commonly said to fall into larger ones with which they communicate, so that these words do not necessarily convey any idea beyond that of mere union; and the writer being near the Euphrates (see the next paragraph of the text,) would naturally describe these canals as tributaries to that river, even had the actual run of the waters been in the other direction. Seeing; however, that these canals were navigable, and that they were of course made without locks, it is manifest that no great difference of level between the two rivers could have existed; and whichever way it may have been, most assuredly there was not, in a country which to this day is almost a dead flat, any opportunity for the one river to "pour its waters into" the other.

Mr. Rich tells us in his Memoir on the Ruins of Babylon (2nd edit. p. 13), that during the inundation of the Euphrates "rafts laden with lime are brought almost every day from Felugiah to within a few hundred yards of the northern gate of Bagdad." This must (I have reason to believe) be understood as referring to a canal existing there, which joins the two rivers, and which is fllled during the flooded season; but even here, no less than $380(600-220)$ miles above the Hie, by which (as Col. Chesney informs us, ) the Euphrates receives the waters of the Tigris, the levels of the two rivers so closely correspond as to allow of a navigable communication existing between them! Mr. Carter has discoursed very learnedly respecting the mode in which rivers produce their deltas, but there appears to be a fundamental defect in his reasoning: he takes as a "fact" that the Tigris "can be more rapid [than the Euphrates] only through flowing from a higher country down a greater slope." But if we look to what is actually the fact, we find that at two distinct points, namely, at Felugiah (opposite Bagdad) and at Khorna, the Tigris and Euphrates are of equal (or nearly equal) heights. Between these two points, however, we have the unquestionable evidence of Col. Chesney that the two rivers are "very different in every respect," the former moving in a rapid and the latter in a dull and lingering stream. This difference in character is clearly not produced by the Tigris "flowing from a higher country down a greater slope," since at Bagdad that river is no higher than the Euphrates at Felugiah. Other causes have therefore to be sought for, among which may be noticed the greater length of the 
Euphrates between these two points and the breadth of its bed in the lower portion of its course, both which causes must produce a corresponding diminution in its speed, and on the other hand the contraction of the channel of the Tigris, which must be attended with a corresponding acceleration of the motion of its waters.

Col. Chesney is referred to as describing the Euphrates as in the present day flowing in a dull and lingering stream: Herodotus, also an eye-roitness, in his description of Babylon talks of the "deep and rapid streams of the great Euphrates*." No one will for a moment doubt the accuracy of Col. Chesney's observation; but is not credit also due to Herodotus? and is he, in like manner as Arrian, to be " unceremoniously thrown overboard," whilst the facts respecting the former condition of these rivers remain unascertained? In the passage last cited, the Halicarnassian traveller further expressly asserts that the Euphrates "discharges itself into the Persian Gulf;" which assertion he confirms in his more detailed statement that that river, "which before flowed in an almost straight line," had its course so turned by Nitocris, that in his time, "those who wished to go from the sea up to Babylon were compelled to touch at Ardericca three times on three different days $\uparrow . "$ Surely such unqualified and unequivocal assertions of plain matters cf fact are entitled to consideration, and are not to be put aside as errors simply because they are not applicable to the present state of things, or rather, perhaps, because they do not coincide with what we have been taught by former commentators to receive as the truth.

[To be continued.]

LXXXVIII. On the Theory of Vanishing Fractions. By J. R. Young, Esq., Professor of Mathematics in Belfast College. $\neq$

IN a letter inserted in the April number of this Journal (p. 295)

I ventured to offer some objections to certain novel positions, lately advanced by an ingenious mathematician, in an Essay on the Fundamental Principles of the Differential and Integral Calculus. To these objections the author of the Essay has furnished a reply, in the number for May (p. 393); and I am happy to find, from the general tone of it, that Mr. Woolhouse has considered my scruples with the same good feeling in which they were avowedly offered.

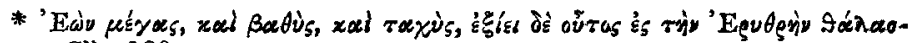
$\sigma a x .-$ Clio, 180.

$\dagger$ Clio, 185 . $\ddagger$ Communicated by the Author. 